\title{
MENGASAH KETERAMPILAN MOTORIK HALUS DALAM KEGIATAN MENGGUNTING DAN MENEMPEL PADA TK AL MAFTUH DI MASA PANDEMI COVID-19
}

\author{
Ai Yanti \\ Pendidikan Anak Usia Dini,Universitas Panca Sakti \\ Email: aiyanti83@gmail.com \\ Fitria Budi Utami \\ Pendidikan Anak Usia Dini,Universitas Panca Sakti \\ Email: fitriabudiutami.2005@gmail.com
}

\begin{abstract}
This research was conducted aimed at improving children's fine motor skills and increasing children's concentration power by cutting and sticking activities. The research was conducted at the Al-Maftuh Kindergarten unit, Sukamulya Village, Sukabumi. Where the researchers conducted research on 25 children of group B AlMaftuh Kindergarten in Sukamulya Village. The research was conducted due to the lack of children's motor results in the previous year, so with this they would like to further improve their fine motor skills to be more thorough and neat in terms of writing, coloring, drawing with cutting and sticking activities where their fingers are trained as well as eye and eye coordination. careful hand.
\end{abstract}

Keywords: cutting, sticking to improve fine motor skills, early childhood

\begin{abstract}
Abstrak: Penelitian ini dilakukan bertujuan untuk meningkatkan kemempuan motoric halus anak dan meningkatkan daya konsentrasi anak dengan kegiatan menggunting dan menempel. Penelitian dilakukan pada satuan TK Al- Maftuh Desa Sukamulya, Sukabumi. Dimana peneliti melakukan penelitian pada 25 anak kelompok B TK Al-Maftuh Desa Sukamulya. Penelitian dilakukan karena minimnya hasil motorik anak pada tahun sebelumnya, maka dengan ini ingin sekali lebih meningkatkan motoric halus mereka agar lebih teliti dan rapih dalam hal menulis, mewarnai, menggambar dengan kegiatan menggunting dan menempel yang mana jari-jari mereka terlatih dan juga koordinasi mata dan tangan yang teliti.
\end{abstract}

Kata Kunci .menggunting,menempel meningkatkan motorik halus, anak usia dini

\section{PENDAHULUAN}

Masa Pandemi civid-19 yang melanda seluruh dunia memang tidak dapat di pungkiri, wabah ini sudah banyak memekan korban jiwa sehingga semua orang harus menjaga kondisi Kesehatan mereka masing masing, yang mana penerapan 3 M (memakai masker, menjaga jarak, mencuci tangan). Segala Tindakan yang dilakukan pemerintah untuk memutus 
Ai Yanti, Fitria Budi Utami, Mengasah Keterampilan Motorik Halus Dalam Kegiatan Menggunting Dan Menempel Pada TK Al Maftuh Di Masa Pandemi Covid-19

mata rantai penyebaran virus covid-19. Salah satu Tindakan pemerintah adalah merumahkan semua kegiatan baik dunia pekerjaan, bisnis, perkantoran, perdagangan, Pendidikan dan semua sektor yang berada pada keramaian. Salah satu yang pernyataan yang dilontarkan oleh mentri Pendidikan yaitu pembelajaran secara daring, yang mana seluruh siswa tidak boleh dating kesekolah, semua siswa sekolah harus melakukan pembelajaran dari rumah.

Banyak cara pembelajaran secara daring dan luring, bagaimana pihak sekolah menyikapinya dan juga pemberitahuan serta memberikan pemahaman kepada orang tua. Guna memutuskan penyebaran virus covid-19, maka semua harus dilaksanakan. Pendidikan adalah sektor penting bagi seluruh dunia,karena tanpa Pendidikan akan bagaimana anak-anak mendapatkan ilmu dan juga hal-hal yang akan membuat mereka menjadi penerus bangsa dan negara. Apapun jenis pembelajaran yang dilakukan harus menjadikan anak-nak tetap semangat dan senang menjalaninya.

Kondisi Pandemi covid-19 tidaklah menghalangi bagi mereka yang memahami teknologi, akan tetapi juga memaksa orang-orang yang tertinggal teknologi untuk belajar dan terus mengembangkan inovasi. Lalu bagaimana dengan Pendidikan/ pembelajaran yang berada pada pelosok desa yang sulit untuk mendapatkan akses internet, bahkan untuk mendapatkan sinyal saja sulit. Dalam hal ini TK Al-Maftuh melakukan pembelajaran secara luring yang mana pembelajaran secara luring ini juga tidak terlalu memberatkan orang tua, sehingga anak-anak mampu mengikuti Pendidikan dan pembelajaran dengan baik. Dimana TK AlMaftuh terletak di desa Sukamulya, Kab. Sukabumi, sulit untuk mendapatkan sinyal dan juga akses internet. 


\section{METODE PENELITIAN}

Penelitian yang dilakukan mencakup model Kemis dan Mc Taggart seperti pada bagan berikut:

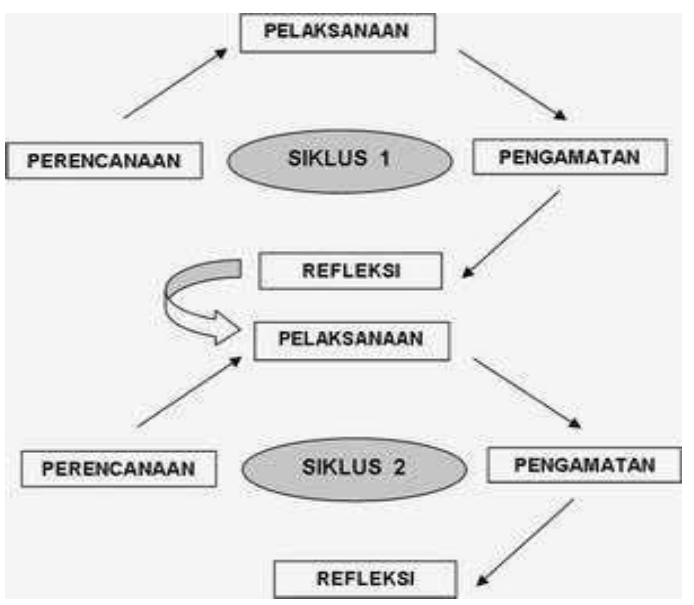

Gambar 1: Bagan Penelitian Tindakan Kelas

Kegiatan penelitian dilakukan pada seluruh anak kelompok B di TK Al-Maftuh yang berjumlah 25 anak. Data yang di teliti menggunakan teknik pengumpulan data observasi melalui Tindakan kelas. Dalam hal ini, pengumpulan data merupakan bagian utama dalam suatu penelitian, bahkan data tersebut sangat mendukung bagi seorang peneliti. Adapun Tindakan-tindakan yang dilakukan adalah sebagai berikut :

\section{1) Observasi}

Observasi adalah Tindakan yang dilakukan oleh seorang guru atau peneliti untuk melihat kemampuan peserta didik dalam melakukan suatu kegiatan tertentu, serta mengukur tingkat kemampuan yang diperoleh oleh peserta didik.

2) Tindakan

Dalam penelitian Tindakan yang dilakukan adalah menggunakan Tindakan kelas. Anak mampu mengembangkan motorik halusnya dengan menggunakan Teknik-teknik Tindakan seperti: menggunting, menempel, 
Ai Yanti, Fitria Budi Utami, Mengasah Keterampilan Motorik Halus Dalam Kegiatan Menggunting Dan Menempel Pada TK Al Maftuh Di Masa Pandemi Covid-19

menarik garis(lurus,bergelombang,zig-zag) dan lain sebagainya yang mampu meningkatkan motorik halus mereka.

3) Penilaian

Penilaian dilakukan pada kegiatan berlangsung, dimana anak merasa kesulitan dan apa Tindakan yang mereka lakukan,apakan anak mampu menyelesaikan kesulitan mereka sendiri atau dibantu oleh gurunya. Dalam hal menggunting contohnya, ada anak yang tidak bisa sama sekali menggunakan gunting karena pergerakan jari-jemari nya yang masih kaku,ada juga anak yang memang sudah mampu menggunakan gunting tetapi belum terarah. Dari Hasil kegiatan yang dilakukan dapat disimpulkan melalui penialain, mana dari kegiatan yang dilakukan tingkat kesulitan/kerumitan yang anak-anak tidak mampu,apa saja dan apa alasannya.

\section{HASIL DAN PEMBAHASAN}

Pada Masa Pandemi memeng membuat kerja keras para pendidik untuk mampu mengikuti perkembangan/perubahan yang terjadi, semua pendidik harus mampu melakukan inovasi-inovasi baru pada masa dengan teknologi. Pada masa Pandemi juga banyak sekolah menggunakan pembelajaran secara daring, akan tetapi berbeda dengan TK Al Maftuh yang mana melakukan pembelajaran secara luring. Luring yaitu pembelajaran yang dilakukan dengan menggunakan media seperti televisi, radio ataupun lembar kerja, dalam hal ini TK Al maftuh menggunakan pembelajaran secara luring (Visit Home). Sehingga pembelajaran dapat berjalan dan sebagaimana mestinya walaupun di tengah pandemic covid 19. Dalam Kegiatan penelitian Tindakan yang akan dikembangkan adalah menambah kemampuan motorik halus anak melalui kegiatan menggunting dan menempel dengan model Kemmis dan Mctaggart. Kemmis dan McTaggart memberikan gambaran bahwa penelitian Tindakan kelas adalah suatu Tindakan berulang yang terdiri dari 
perencanaan, pelaksanaan Tindakan, observasi, dan refleksi. Pada penelitian ini di lakukan dengan Tindakan kelas karena PTK memberikan solusi baru untuk memperbaiki dan meningkatkan kemampuan atau profesionalisme guru dalam kegiatan pembelajaran kelas. Menurut kunandar penelitian Tindakan kelas adalah penelitian yang dilakukan untuk meningkatkan mutu serta kwalitas peserta didik ${ }^{1}$.

Menggunting adalah memotong bahan dari kertas atau bahan-bahan lain dengan mengikuti alur, garis atau bentuk-bentuk tertentu². Kemampuan menggunting seseorang dapat dilihat dari mulai cara memegang gunting, menggerakkan gunting, serta mengarahkan guntingan sesuai pola yang akan di gunting ${ }^{3}$. Menempel adalah kegiatan yang dilakukan dalam penyelesaian membuat bentuk kerajinan dari bahan kertas atau bahan lain yang sudah di gunting dengan menggunakan lem dan menggunakan jari-jari tangan ${ }^{4}$. Menurut Hasnida mengatakan arti motorik halus adalah Gerakan yang membutuhkan kerjasama mata dan tangan dengan menggunakan otot-otot halus saja ${ }^{5}$. Dalam kegiatan menggunting dan menempel dengan rencana pembelajaran harian yang silakukan pada prasiklus,siklus I dan siklus II dapat dilihat pada tabel berikut ini:

\footnotetext{
${ }^{1}$ Antari, L. (2015). Penggunaan Bahan Ajar Tematik Pembagian Untuk Meningkatkan Hasil Belajar Di Kelas IIA MI Ahliyah II Palembang. AKSIOMA: Jurnal Program Studi Pendidikan Matematika, 4(2).

2 Sumantri. (2005). Model Pengembangan Keterampilan Motorik Anak Usia Dini. Jakarta: Depdiknas, H.152

${ }^{3}$ Mahoney, S., \& Markwell, A. (2004). Developping Scissor Skills: A Guide for Parents and Teachers. Peta (UK) Limited.

${ }^{4}$ Sumantri. (2005). Model Pengembangan Keterampilan Motorik Anak Usia Dini. Jakarta: Depdiknas

${ }^{5}$ Widayati, S., Adhe, K. R., Nafisa, F., \& Silvia, E. F. (2019). Tahapan Menggunting dalam Meningkatkan Kemampuan Motorik Halus Anak Usia Dini. Child Education Journal, 1(2), 50-57.
} 
Ai Yanti, Fitria Budi Utami, Mengasah Keterampilan Motorik Halus Dalam Kegiatan Menggunting Dan Menempel Pada TK Al Maftuh Di Masa Pandemi Covid-19

Tabel 1. Nilai yang diperoleh pada pra siklus, siklus 1 dan siklus 2

\begin{tabular}{|c|c|c|c|c|c|c|c|}
\hline \multirow{2}{*}{ No } & \multirow{2}{*}{ Observasi } & \multicolumn{2}{|c|}{ Pra siklus } & \multicolumn{2}{c|}{ Siklus I } & \multicolumn{2}{c|}{ Siklus II } \\
\cline { 3 - 8 } & & $\begin{array}{c}\text { Cara } \\
\text { memegang } \\
\text { gunting }\end{array}$ & $\begin{array}{c}\text { Mampu } \\
\text { menggunakan } \\
\text { gunting }\end{array}$ & $\begin{array}{c}\text { Cara } \\
\text { memegang } \\
\text { gunting }\end{array}$ & $\begin{array}{c}\text { Mampu } \\
\text { menggunakan } \\
\text { gunting }\end{array}$ & $\begin{array}{c}\text { Cara } \\
\text { Memegang } \\
\text { gunting }\end{array}$ & $\begin{array}{c}\text { Mampu } \\
\text { Menggunakan } \\
\text { Gunting }\end{array}$ \\
\hline 1 & BB & 25 & 15 & 25 & 6 & 25 & 2 \\
\hline 2 & MB & 25 & 10 & 25 & 16 & 25 & 2 \\
\hline 3 & BSH & 0 & 0 & 25 & 3 & 25 & 3 \\
\hline 4 & BSB & 0 & 0 & 0 & 0 & 25 & 18 \\
\hline
\end{tabular}

Dalam table di bawah ini dengan perhitungan :

Pra siklus

$\mathrm{BB}=15 / 25 \times 100=60 \%$ $\mathrm{MB}=10 / 25 \times 100=40 \%$
Siklus I

$\mathrm{BB}=6 / 25 \times 100=24 \%$

$\mathrm{MB}=16 / 25 \times 100=64 \%$ $\mathrm{BSH}=3 / 25 \times 100=12 \%$
$\mathrm{BB}=2 / 25 \times 100=8 \%$

$\mathrm{MB}=2 / 25 \times 100=8 \%$

$\mathrm{BSH}=3 / 25 \times 100=12 \%$ $\mathrm{BSB}=18 / 25 \times 100=72 \%$

\begin{tabular}{|c|c|c|c|}
\hline Observasi & $\begin{array}{c}\text { Pra } \\
\text { Siklus }\end{array}$ & Siklus I & Siklus II \\
\hline BB & $60 \%$ & $24 \%$ & $8 \%$ \\
\hline MB & $40 \%$ & $64 \%$ & $8 \%$ \\
\hline BSH & 0 & $12 \%$ & $12 \%$ \\
\hline BSB & 0 & 0 & $72 \%$ \\
\hline
\end{tabular}

Nilai Pra Siklus, Siklus 1, Siklus 2

6

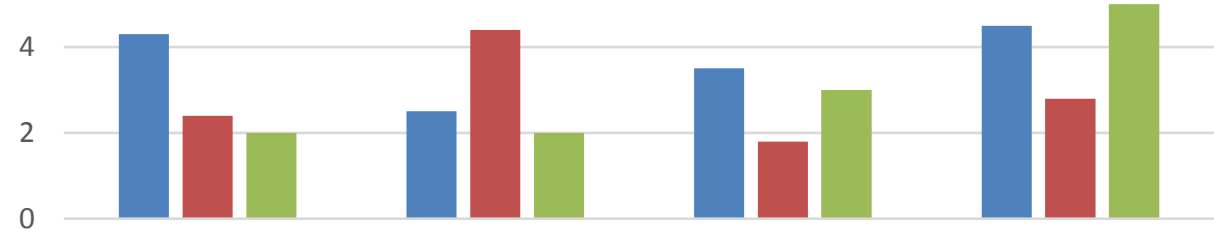

$\mathrm{BB}$

$\mathrm{MB}$

$\mathrm{BSH}$

BSB

a Series 1 Series $2 \square$ Series 3

Grafik 1. Nilai yang diperoleh pada pra siklus, siklus 1 dan siklus 2

BB : Belum Berkembang

MB : Mulai Berkembang

BSH : Berkembang Sesuai Harapan

BSB : Berkembang Sangat Baik 


\section{KESIMPULAN}

Berdasarkan hasil penelitian yang dilakukan pada siklus II sudah mengalami perubahan yang baik dari prasiklus banyak anak yang belum mampu mengoprasikan atau menggunakan gunting dan akhirnya anak mampu menggunakan dengan baik mencapai $72 \%$ dari 18 siswa yang berkembang sangat baik. Berdasarkan penelitian ini dapat disimpulkan bahwa penggunaan menggunting dan menempel mampu meningkatkan motorik halus anak melalui kelenturan jari-jari tangan mereka yang bergerak secara bersamaan dengan koordinasi mata yang seimbang. Sehingga penelitian dikatakan berhasil karena tingkat pencapain sudah mencapai $72 \%$ dari keseluruhan siswa 25 (100\%).

\section{DAFTAR PUSTAKA}

Agustin, M., Puspita, R. D., Nurinten, D., \& Nafiqoh, H. (2020). Tipikal Kendala Guru PAUD dalam Mengajar pada Masa Pandemi Covid 19 dan Implikasinya. Jurnal Obsesi : Jurnal Pendidikan Anak Usia Dini, 5(1), 334. https://doi.org/10.31004/obsesi.v5i1.598

Antari,L. (2015). Penggunaan Bahan Ajar Tematik Pembagian untuk Meningkatkan Hasil Belajar Dikelas IIA MI Ahliyah II Palembang. AKSIOMA: Jurnal Program Studi Pendidikan Matematika, 4(2).

Arikunto, S. (2010). Prosedur Penelitian Suatu Pendekatan Praktek. Jakarta: Rineka Cipta.

Fadhilaturrahmi, F. (2017). PENERAPAN METODE MIND MAPPING UNTUK MENINGKATKAN HASIL BELAJAR MAHASISWA SEMESTER IIA PGSD MATAKULIAH PENDIDIKAN MATEMATIKA SD KELAS RENDAH. Jurnal Cendekia: Jurnal Pendidikan Matematika, 1(1), 112-121.

Ismawati, D., \& Prasetyo, I. (2020). Efektivitas Pembelajaran Menggunakan Video Zoom Cloud Meeting pada Anak Usia Dini Era Pandemi Covid-19. Jurnal Obsesi: Jurnal Pendidikan Anak Usia Dini, 5(1), 665. https://doi.org/10.31004/obsesi.v5i1.671

Kandupi, A. A. R. D. Pengaruh Alat Permainan Edukatif Terhadap Perkembangan Motorik Halus Anak di Kelompok B3 TK Aisyiyah V Palu. Bungamputi, 4(3).

Mahoney, S., \& Markwell, A. (2004). Developping Scissor Skills: A Guide 
Ai Yanti, Fitria Budi Utami, Mengasah Keterampilan Motorik Halus Dalam Kegiatan Menggunting Dan Menempel Pada TK Al Maftuh Di Masa Pandemi Covid-19

for Parents and Teachers. Peta (UK) Limited.

Malyana, A. (2020). Pelaksanaan Pembelajaran Daring dan Luring Dengan Metode Bimbingan Berkelanjutan Pada Guru Sekolah Dasar Di Teluk Betung Utara Bandar Lampung. Jurnal IImiah Pendidikan Dasar Indonesia, 2(1), 67-76

Montolalu, BEF, dkk 2015. Bermain dan Permainan : Jakarta Universitas Terbuka

Pamadhi.2008. Seni Ketra mpilan Anak. Universitas Terbuka

Rasmitadila, Aliyyah, R. R., Rachmadtullah, R., Samsudin, A., Syaodih, E., Nurtanto, M., \& Tambunan, A. R. S. (2020). The perceptions of primary school teachers of online learning during the covid-19 pandemic period: A case study in Indonesia. Journal of Ethnic and Cultural Studies, 7(2), 90-109. https://doi.org/10.29333/ejecs/388

Robinson, L. E., Webster, E. K., Logan, S. W., Lucas, W. A., \& Barber, L. T. (2012). Teaching Practices that Promote Motor Skills in Early Childhood Settings. Early Childhood Education Journal, 40(2), 7986. https://doi.org/10.1007/s10643-011-0496-3

Rochiati Wiriaatmadja. (2006). Metode Penelitian Tindakan Kelas. Bandung: Remaja Rosdakarya

Rumini,Sri dan Siti, Sundari.2004. Perkembangan Anak dan Remaja. Jakarta: Rineka Ciptaeks

Sudiarni, B. N., \& Gunawan ,I. M. (2021). Analisis Pengaruh Media Bahan Bekas Terhadap Keterampilan Motorik Halus pada Anak Usia 5-6 Tahun di PAUD Al Hikmah. Jurnal Paedagogy,8 (4), 594-599

Sukayati, M. P., Shadiq, F., \& Yuliawanto, M. S. (2018). Penelitian tindakan kelas.

Sumantri. (2005). Model Pengembangan Keterampilan Motorik Anak Usia Dini. Jakarta: Depdiknas

Szente, J. (2020). Live Virtual Sessions with Toddlers and Preschoolers amid COVID-19: Implications for Early Childhood Teacher Education. Journal of Technology and Teacher Education, 28(2), 373-380.

Tandon, P., Hassairi, N., Soderberg, J., \& Joseph, G. (2020). The relationship of gross motor and physical activity environments in child care settings with early learning outcomes. Early Child Development and Care,190(4),570-579.

Temple, V. A., Crane, J. R., Brown, A., Williams, B. L., \& Bell, R. I. (2016). 
Recreational activities and motor skills of children in kindergarten. Physical Education and Sport Pedagogy, 21(3), 268-280. https://doi.org/10.1080/17408989.2014.924494

Wainwright, N., Goodway, J., John, A., Thomas, K., Piper, K., Williams, K., \& Gardener, D. (2020). Developing children's motor skills in the Foundation Phase in Wales to support physicalliteracy. Education313,48(5), 565-579. https://doi.org/10.1080/03004279.2019.1633374

Widayati, S., Adhe, K. R., Nafisa, F., \& Silvia, E. F. (2019). Tahapan Menggunting dalam Meningkatkan Kemampuan Motorik Halus Anak Usia Dini. Child Education Journal, 1(2), 50-57.

Widayati, S., Adhe, K. R., Nafisa, F., \& Silvia, E. F. (2019). Tahapan Menggunting dalam Meningkatkan Kemampuan Motorik Halus Anak Usia Dini. Child Education Journal, 1(2), 50-57.

Yao Jijun, C. X. (2020). What Role Should Teachers Play in Online Teaching during the COVID- 19 Pandemic? Evidence from China. Science Insights Education Frontiers, 5(2), 517-524. https://doi.org/10.15354/sief.20.ar035

Zhang, L., Sun, J., Richards, B., Davidson, K., \& Rao, N. (2018). Motor Skills and Executive Function Contribute to Early Achievement in East Asia and the Pacific. Early Education and Development, 29(8),1061-1080https://doi.org/10.1080/10409289.2018.1510204 